UDC 621.914 .1

\title{
Influence of the Cut Axial Depth on Surface Roughness at High-Speed Milling of Thin-Walled Workpieces
}

\author{
A. I. Germashev ${ }^{1)}$, V. A. Logominov' $^{1)}$, S. I. Dyadya ${ }^{1)}$, Y. B. Kozlova ${ }^{1)}$, V. A. Krishtal' \\ ${ }^{1)}$ National University “Zaporizhzhya Polytechnic” (Zaporozhye, Ukraine), \\ ${ }^{2)} \mathrm{SE}$ “Ivchenko-Progress” (Zaporozhye, Ukraine) \\ (C) Белорусский национальный технический университет, 2021 \\ Belarusian National Technical University, 2021
}

\begin{abstract}
The paper presents the results of research on the dynamics of end milling of thin-walled work-pieces having complex geometric shapes. Since the milling process with shallow depths of cut is characterized by high intermittent cutting, the proportion of regenerative vibrations decreases, and the effect of forced vibrations on the dynamics of the process, on the contrary, increases. The influence of axial depth of cut on the vibrations arising during processing, and roughness of the processed surface have been studied in paper. The experiments have been carried out in a wide range of changes in the spindle speed at different axial cutting depths. Vibrations of a thin-walled work-piece have been recorded with an inductive sensor and recorded in digital form. Then an oscillogram has been used to estimate the amplitude and frequency of oscillations. The profilograms of the machined surface have been analysed. Roughness has been evaluated by the parameter Ra. The results have shown similar relationships for each of the investigated axial cutting depths. The worst cutting conditions have been observed when the natural vibration frequency coincided with the tooth frequency or its harmonics. It is shown that the main cause of vibrations in high-speed milling is forced rather than regenerative vibrations. Increasing the axial depth of cut at the same spindle speed increases the vibration amplitude. However, this does not significantly affect the roughness of the processed surface in cases when it comes to vibration-resistant processing.
\end{abstract}

Keywords: milling, thin-walled work-piece, high-speed milling, forced vibrations, vibrations, self-excited oscillations, spindle speed

For citation: Germashev A. I., Logominov V. A., Dyadya S. I., Kozlova Y. B., Krishtal V. A. (2021) Influence of the Cut Axial Depth on Surface Roughness at High-Speed Milling of Thin-Walled Workpieces. Science and Technique. 20 (2), 127-131. https://doi.org/10.21122/2227-1031-2021-20-2-127-131

\section{Влияние осевой глубины резания на шероховатость поверхности при высокоскоростном фрезеровании тонкостенных деталей}

\author{
Канд. техн. наук А. И. Гермашев ${ }^{1)}$, \\ кандидаты техн. наук, доценты В. А. Логоминов ${ }^{1)}$, С. И. Дядя ${ }^{1)}$, Е. Б. Козлова ${ }^{1)}$, \\ В. А. Кришталь ${ }^{2)}$ \\ ${ }^{1)}$ Национальный университет «Запорожская политехника» (Запорожье, Украина), \\ ${ }^{2)} Г П$ «Ивченко-Прогресс» (Запорожье, Украина)
}

Реферат. В статье представлены результаты исследований динамики концевого фрезерования тонкостенных деталей сложной геометрической формы. Поскольку процесс фрезерования с малыми глубинами резания характеризуется высокой прерывистостью резания, доля регенеративных колебаний уменьшается, а влияние вынужденных колебаний на динамику процесса, напротив, увеличивается. Изучено влияние осевой глубины резания на колебания, возникающие

\author{
Адрес для переписки \\ Козлова Елена Борисовна \\ Национальный университет «Запорожская политехника» \\ ул. Жуковского, 64, \\ 69063, г. Запорожье, Украина \\ Тел.: +380 61 769-83-16 \\ kozlova@zntu.edu.ua
}

\author{
Address for correspondence \\ Kozlova Yelena B. \\ National University "Zaporizhzhya Polytechnic" \\ 64, Zhukovsky str., \\ 69063, Zaporozhye, Ukraine \\ Tel.: +380 61 769-83-16 \\ kozlova@zntu.edu.ua
}


при обработке, и шероховатость обработанной поверхности. Опыты проводили на специально сконструированном стенде, позволяющем раздельно исследовать влияние режимов резания и динамических характеристик тонкостенной детали на динамику фрезерования. Эксперименты выполнены в широком диапазоне изменений скорости вращения шпинделя при различных осевых глубинах резания. Колебания тонкостенной детали регистрировали индуктивным датчиком и записывали в цифровом виде. Затем по осциллограмме оценивали амплитуду и частоту колебаний. Проанализированы профилограммы обработанной поверхности. Шероховатость оценивали по параметру Ra. Результаты показали схожие зависимости для каждой из исследованных осевых глубин резания. Наихудшие условия резания наблюдались в случаях, когда собственная частота колебаний совпадала с зубцовой частотой или ее гармониками. Показано, что основной причиной вибраций при высокоскоростном фрезеровании являются вынужденные, а не регенеративные колебания. Увеличение осевой глубины резания при одинаковых частотах вращения шпинделя повышает амплитуду колебаний. Однако это несущественно влияет на шероховатость обработанной поверхности в случаях, когда речь идет о виброустойчивой обработке.

Ключевые слова: фрезерование, тонкостенная деталь, высокоскоростное фрезерование, вынужденные колебания, вибрации, автоколебания, частота вращения шпинделя

Для цитирования: Влияние осевой глубины резания на шероховатость поверхности при высокоскоростном фрезеровании тонкостенных деталей / А. И. Гермашев [и др.] // Наука и техника. 2021. Т. 20, № 2. С. $127-131$. https://doi.org/10.21122/2227-1031-2021-20-2-127-131

\section{Introduction}

The key factor in thin wall machining is the dynamic behaviour of the work-piece. Thin-walled milling case covers many parts of the aerospace sector, including structural and engine parts. Thus, operating conducted under 5 axes milling which is widely used in manufacturing blisk or impellers [1]. Biermann et al. [2] presented a general approach to simulate work-piece vibrations during 5 axes milling of turbine blades. Budak et al. [3] included the effect of work-piece dynamics on chatter stability in milling of turbine blades, taking into account constant changes of the part characteristic. Thin-walled parts behavior is highly dependent from tool position due to continuously changeable structural dynamics. Path dependent 3D stability diagrams was developed to determine dynamic of the part along tool path and reaching free of chatter machining of thinwalled work-pieces [4], [5]. Munoa at al. [6] concluded that the main tendency in chatter avoidance during thin-walled machining is the use FEM models to predict the modal parameters and vibration modes, considering the variations due to material removal. One of the first study of thin-walled milling with FEM model was carried out by Kline et al. [7]. Further improving of this model was made by Budak and Altintas [8] considering the plate surface finish.

One of the important specifics of thin-walled milling of engine parts is highly interrupted nature and high spindle speed, where influence of chatter becomes lower due to low fraction of the wave [9].
In such case the surface location error regularities take place, that was noticed by Kline et al. [10], [11], Tlusty [12], Montgomery and Altintas [13, 14], Smith et al. [15], Tarng et al. [16], Schmitz et al. [17-21], and others. Therefore, even under seemly stable cutting conditions, the thin-walled structures experience forced vibrations, which depend on the work-piece / tool natural frequency and excitation frequency (or tooth passing frequency), causing big fluctuations of the flexible workpiece.

As at highly interrupted machining chatter has low influence on the state of milling process while poliresonance cause high oscillation at certain spindle speed ranges, primary goal of the paper showing that generally accepted parameter of axial depth of cut has low influence on the state of machining if good spindle speed range is reached. For validation of proposed assumption experimental study is proposed.

\section{Experimental setup}

Data acquisition for thin-walled end milling process has some features related to the specifics of this process. Due to the high intermittency of thin-walled end milling process it consists of consecutive alternation of cutting and free movement of the part. Part behaviour during milling process affects quality of surface finish, dimensional accuracy, manufacturing tool wear, etc. By the time free movement of the part is not so important, because of tool-work-piece system break. Moreover, free oscillations of the part might have bigger amplitude than part deflection during milling. However, data acquisition records all machining 
process. So, to evaluate thin-walled milling process accurately, it becomes significantly important to separate cutting process from the entire processing signal. Such procedure is carried out by measuring contact system of experimental setup, which allows recording a contact signal simultaneously with the displacement sensor that measures oscillation of thin plate during processing (Fig 1).

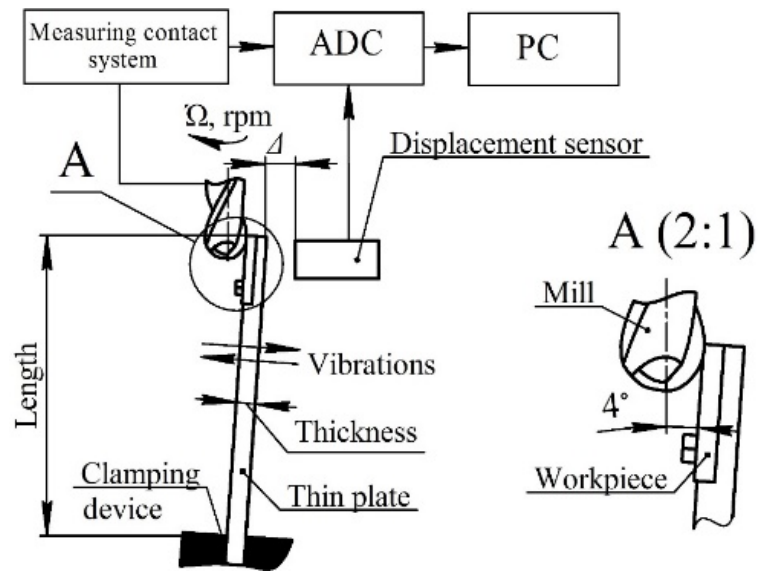

Fig. 1. Experiment setup

\section{Results}

For investigating the axial depth of cut influence on the state of machining at milling of thinwalled components, two series of experimental tests were conducted with parameter $a_{e}=0.5 \mathrm{~mm}$ and $a_{e}=1.5 \mathrm{~mm}$. Maximal amplitude of the part oscillation was measured during the tests.

In Fig. 2 it is shown part's amplitude oscillation changes at different spindle speeds. For both series of experimental tests it was observed the same regularities and spindle speed ranges with low and high amplitudes. The biggest amplitude was observed at spindle speed $n=2700-3000 \mathrm{rpm}$, $n=3500-4500 \mathrm{rpm}, n=7700-8500 \mathrm{rpm}$, while low amplitude was noticed at $n=3100-3500 \mathrm{rpm}$, $n=5300-6900 \mathrm{rpm}, n=9500-10000 \mathrm{rpm}$.

As poliresonance has a dominant influence at highly interrupted machining of thin-walled components it is proposed to observe this chart in terms of tooth passing and natural frequency ratio (Fig. 3). From this chart it is easy to notice that maximum amplitude was observed at the ratio $1.0,0.5,0.33$ and close to them regions. The lowest amplitude was seen at $0.75,0.44$ and lower then 0.3 . It should be noticed that if time of cutting becomes more than period of chatter conditions are conductive to appearance of chatter. For this and other reasons, the polyresonance does not have a dominant influence on the cutting process at low passing and natural frequency ratio.

The surface quality is presented in the Fig. 4. Curves have similar trends as in the figure of the part oscillation (Fig. 2). Such regularities are described in authors' work [9]. This chart shows sensitivity of thin-walled components to cutting conditions. Taking into account observed spindle speed range the surface roughness changes more than in 20 times for certain spindle speeds (for example at $n=3700 \mathrm{rpm}$ ). In some cases spindle speed difference is less than $5 \%$ (for example at $n=3500 \mathrm{rpm}$ ).

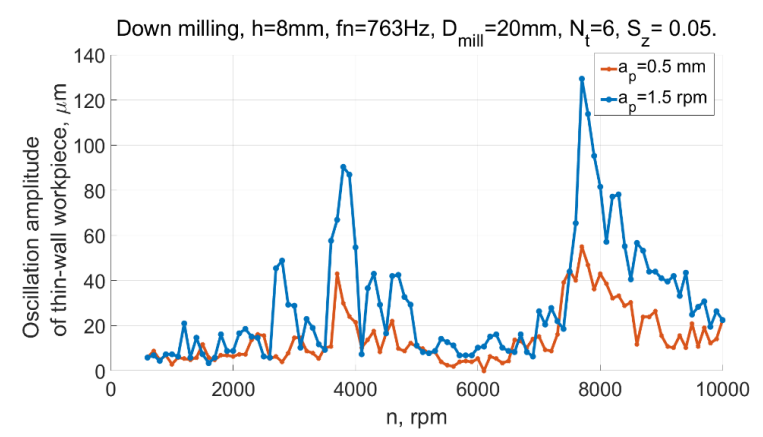

Fig. 2. Dependence of oscillation amplitude on spindle speed chart

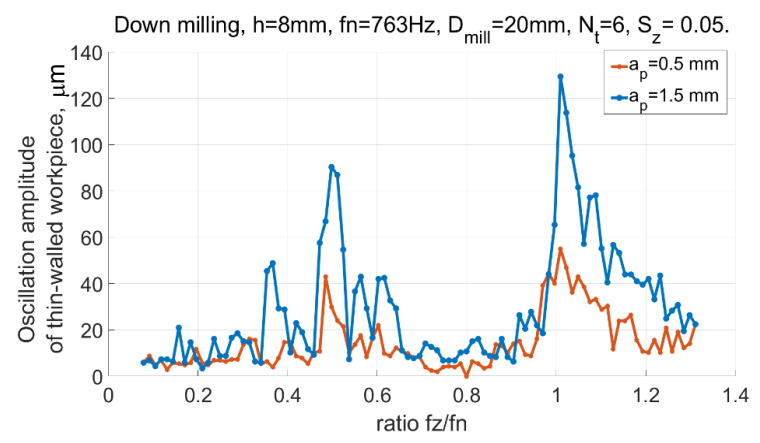

Fig. 3. Dependence of oscillation amplitude on tooth passing and natural frequency ratio

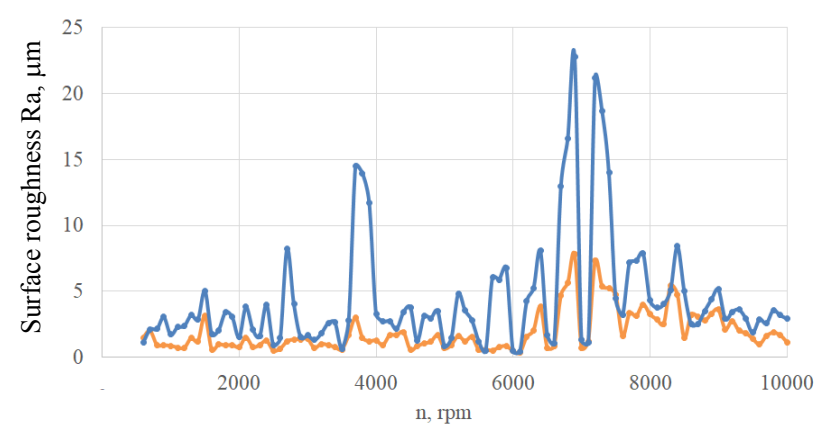

Fig. 4. Dependence of surface roughness on spindle speed chart: $\rightarrow-0.5 ;--1.5$ 
In the Fig. 5 profilograms of machined surface after experimental tests is shown. For the comparison milling condition with the max and min part oscillation level is chosen. These profiles shows that in case of small oscillation increasing of axial depth of cut does not significantly influence on the cutting process. Amplitude of the work-piece oscillation and surface roughness rise less than $30 \%$.
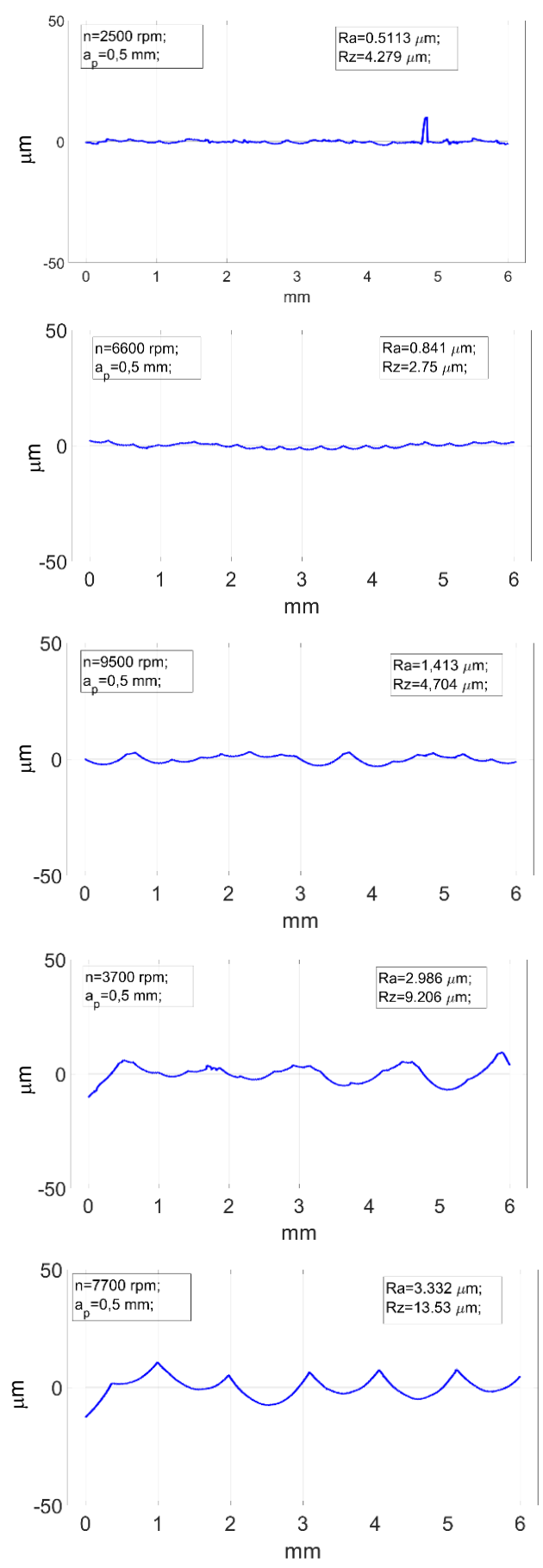

In the same time in case of bad state of machining bigger axial depth of cut causes much more higher oscillation level (more than in 2 times) and damage of the surface. Such results allows to notice that at highly interrupted milling poliresonance regularities usage allows to increase axial depth of cut and save good quality of the machining.
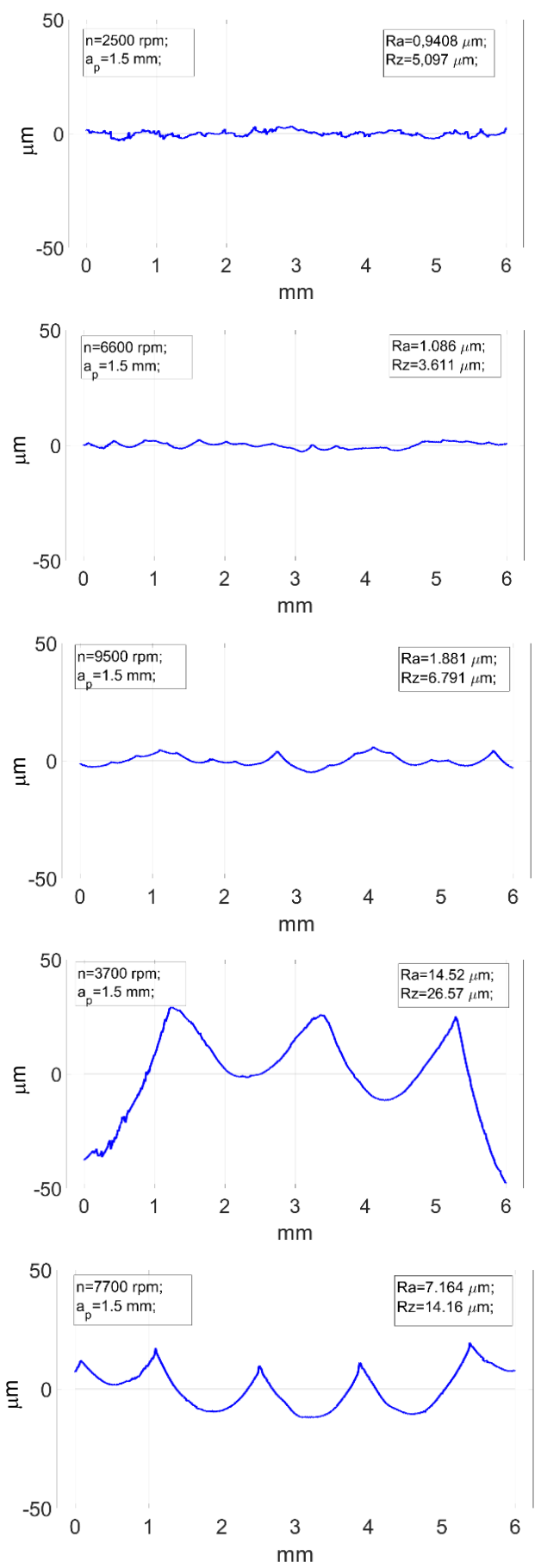

Fig. 5. Profile of the machined surface at max and min oscillation level of the workpiece 


\section{CONCLUSION}

Paper proposes experimental investigations of the influence axial depth of cut on the state of thinwalled milling and quality of surface finish. Based on the results it should be concluded, that thinwalled parts are extremely sensitive to spindle speed variation as their behavior during processing depends on excitation frequency. Analyses of the part oscillation and surface roughness show that spindle speed determines the influence of the axial depth of cut. If spindle speed range with good state of cut is reached, increasing of axial depth of cut does not provide significant changes in the cutting process and machining quality. In either case, if oscillation with high amplitude is observed, an axial depth of cut plays an essential role in increasing vibration level. And furthermore, a high vibration level may lead to damage surface and tool breaking.

\section{REFERENCES}

1. Budak E., Ozturk E., Tunc L. T. (2009) Modeling \& Simulation of 5-Axis Milling Processes. CIRP Annals, 58 (1), 347-350. https://doi.org/10.1016/j.cirp.2009.03.044.

2. Biermann D., Kersting P., Surmann T. (2010) A General Approach to Simulating Workpiece Vibrations During Five-Axis Milling of Turbine Blades. CIRP Annals, 59 (1), 125-128. https://doi.org/10.1016/j.cirp.2010.03.057.

3. Budak E., Tunc L. T., Alan S., Özgüven H. N. (2012) Prediction of Workpiece Dynamics \& its Effects on Chatter Stability in Milling. CIRP Annals, 61 (1), 339-342. https://doi.org/10.1016/j.cirp.2012.03.144.

4. Bravo U., Altuzarra O., Lopez Lacalle L. N., Sanchez J. A., Campa F. J. (2005) Stability Limits of Milling Considering the Flexibility of the Workpiece \& the Machine. International Journal of Machine Tools \& Manufacture, 45 (15), 1669-1680. https://doi.org/10.1016/j.ijmachtools. 2005.03.004.

5. Thevenot V., Arnaud L., Dessein G., Cazenave-Larroche G. (2006) Integration of Dynamic Behavior Variations in the Stability Lobes Method: 3D Lobes Construction \& Application to Thin-Walled Structure Milling. The International Journal of Advanced Manufacturing Technology, 27 (7-8), 638-644. https://doi.org/10.1007/s00170-004-2241-1.

6. Munoa J., Beudaert X., Dombovari Z., Altintas Y., Budak E., Brecher C. Stepan G. (2016) Chatter Suppression Techniques in Metal Cutting. CIRP Annals, 65 (2), 785-808. https://doi.org/10.1016/j.cirp.2016.06.004.

7. Budak E., Altintas Y. (1995) Modeling \& Avoidance of Static Form Errors in Peripheral Milling of Plates. International Journal of Machine Tools \& Manufacture, 35 (3), 459-476. https://doi.org/10.1016/0890-6955(94)p2628-s.

8. Kline W. A., DeVor R. E., Shareef I. A. (1982) The Prediction of Surface Accuracy in Milling. Journal Enginee- ring for Industry, 104 (3), 272-278. https://doi.org/10. 1115/1.3185830.

9. Germashev A., Logominov V., Anpilogov D., Vnukov Y., Khristal V. (2018) Optimal Cutting Condition Determination for Milling Thin-Walled Details. Advances in Manufacturing, 6 (3), 280-290. https://doi.org/10.1007/s40436018-0224-y.

10. Kline W., DeVor R., Shareef I. (1982) The Prediction of Surface Accuracy in End Milling. Journal of Engineering for Industry, 104, 272-278. https://doi.org/10.1115/1. 3185830.

11. Kline W., DeVor R., Lindberg J. (1982) The Prediction of Cutting Forces in End Milling with Application to Cornering Cuts. International Journal of Machine Tool Design Research, 22, 7-22. https://doi.org/10.1016/0020-7357 (82)90016-6.

12. Tlusty J. (1985) Effect of end Milling Deflections on Accuracy. Handbook of High-Speed Machining Techno$\log y, 140-153$.

13. Altintas Y., Montgomery D., Budak E. (1992) Dynamic Peripheral Milling of Flexible Structures. Journal of Engineering for Industry, 114 (2), 137-145. https://doi.org/10. 1115/1.2899766.

14. Montgomery D., Altintas Y. (1991) Mechanism of Cutting Force and Surface Generation in Dynamic Milling. Journal of Engineering for Industry, 113 (2), 160-168. https://doi. org/10.1115/1.2899673.

15. Smith S., Tlusty J. (1991) An Overview of Modeling and Simulation of the Milling Process. Journal of Engineering for Industry, 113 (2), 169-175. https://doi.org/10.1115/1. 2899674.

16. Tarng Y., Liao C., Li H. (1994) A Mechanistic Model for Prediction of the Dynamics of Cutting Forces in Helical End Milling. International Journal of Modeling and Simulation, 14 (2), 92-97. https://doi.org/10.1080/02286203. 1994.11760220.

17. Schmitz T., Ziegert J. (1999) Examination of Surface Location Error due to Phasing of Cutter Vibrations. Precision Engineering, 23, 51-62. https://doi.org/10.1016/s0 141-6359(98)00025-7.

18. Schmitz T. L., Couey J., Marsh E., Mauntler N., Hughes D. (2007) Runout Effects in Milling: Surface Finish, Surface Location Error, and Stability. International Journal of Machine Tools and Manufacture, 47 (5), 841-851. https://doi.org/10.1016/j.ijmachtools.2006.06.014.

19. Schmitz T. L., Ziegert J. C., Canning J. S., Zapata R. (2008) Case Study: a Comparison of Error Sources in High-Speed Milling. Precision Engineering, 32, 126-133.

20. Schmitz T. L., Mann B. P. (2006) Closed-Form Solutions for Surface Location Error in Milling. International Journal of Machine Tools and Manufacture, 46 (12-13), 1369-1377. https://doi.org/10.1016/j.ijmachtools.2005. 10.007 .

21. Schmitz T. L., Smith K. S. (2009) Machining Dynamics: Frequency Response to Improved Productivity. SpringerVerlag US. https://doi.org/10.1007/978-0-387-09645-2.

Received: 21.05 .2020

Accepted: 28.07 .2020

Published online: 30.03 .2021 